\title{
CLIL in Italy: A General Overview
}

Letizia CINGANOTTO*

\begin{abstract}
CLIL (Content and Language Integrated Learning) was introduced in the Italian school system in 2003 through a Reform Law, which made it mandatory for upper secondary schools. This paper is aimed at describing the most important steps of this innovation, with the relevant implications for policymakers, teachers and students. Italy's CLIL mandate is conceptualized as a national language education policy within the larger European plurilingualism discourse, which represents the background of this paper. After a brief overview of the main conceptual frameworks and of CLIL provision in Europe, the paper will try to describe the current status of CLIL in Italy considering the Italian educational system according to the latest legislation. Reference to the national CLIL teacher profile and to the national teacher training action will be taken. Some pilot projects involving school networks will be also mentioned. Particular attention will be devoted to CLIL implementation in "licei linguistici", the Italian upper secondary school that is most oriented to foreign languages. Finally, some future challenges will be highlighted.
\end{abstract}

Keywords: CLIL in Italy; Italian School Reforms; CLIL teacher profile; CLIL teacher training; CLIL projects.

* orcid.org/00oo-0003-3541-7036. INDIRE, Italy. l.cinganotto@indire.it

Received: 2016-11-03 / Sento for peer review: 2016-11-03 / Accepted by peers: 2016-11-08 / Approved: 2016-11-16 To reference this article in APA style / Para citar este artículo en APA / Para citar este artigo

Cinganotto, L. (2016). CLIL in Italy: A general overview. Latin American Journal of Content and Language Integrated Learning, 9(2), 374-400. doi:10.5294/laclil.2016.9.2.6 


\section{CLIL en Italia: una perspectiva general}

\section{Resumen}

El enfoque AICLE se introdujo en el sistema escolar italiano en 2003 a través de una reforma que estableció su aplicación obligatoria en las escuelas de enseñanza secundaria superior. Este documento tiene por objeto describir las etapas más importantes de esta innovación, resaltando las implicaciones más relevantes para docentes, alumnos y aquellos agentes responsables de la formulación de políticas. La misión del enfoque AICLE en Italia se puede conceptualizar como una política lingüistica nacional dentro del ámbito del discurso del plurilingüismo europeo, lo que representa el trasfondo de este estudio. Después de una breve introducción a los principales marcos conceptuales y a la provisión de AICLE en Europa, el documento intenta describir el estado actual del enfoque en Italia, teniendo en cuenta el sistema educativo italiano según la legislación más reciente. Se hace referencia al perfil docente nacional del AICLE y a las acciones de formación docente a nivel nacional. Además, se mencionan algunos proyectos piloto que han involucrado redes de escuelas. Luego, se da especial atención a la implementación del enfoque AICLE en los "Licei Linguistici", las escuelas secundarias superiores italianas con orientación más amplia a las lenguas extranjeras. Finalmente, se destacan algunos desafíos para el futuro.

Palabras clave: AICLE en Italia; reforma de la escuela italiana; perfil del docente AICLE; formación docente AICLE; proyectos AICLE. 


\section{AICLE/CLIL na Itália: uma perspectiva geral}

\section{Resumo}

A abordagem AICLE/CLIL foi introduzida no sistema escolar italiano em 2003 por meio de uma reforma que estabeleceu sua aplicação obrigatória nos colégios de ensino médio. Este documento tem como objetivo descrever as etapas mais importantes dessa inovação e ressaltar as implicações mais relevantes para docentes, estudantes e aqueles agentes responsáveis pela formulação de políticas. A missão da abordagem AICLE/CLIL na Itália pode ser conceituada como uma política linguística nacional no âmbito do discurso do plurilinguismo europeu, o que representa o contexto deste estudo. Após uma breve introdução dos principais referentes conceituais e da provisão da AICLE/CLIL na Europa, neste documento, tenta-se descrever o estado atual da abordagem na Itália considerando o sistema educativo italiano segundo a legislação mais recente. Faz-se referência ao perfil docente nacional da AICLE/CLIL e às ações de formação docente no país. Além disso, mencionam-se alguns projetos piloto que envolveram redes de escolas. Em seguida, dá-se especial atenção à implantação da abordagem AICLE/CLIL nos "Licei Linguistici", colégios de ensino médio com orientação mais ampla às línguas estrangeiras. Finalmente, destacam-se alguns desafios para o futuro.

Palavras-chave: AICLE/CLIL na Itália; formação docente na AICLE/CLIL; perfil docente AICLE/CLIL; projetos AICLE/CLIL; reforma da escola italiana. 


\section{INTRODUCTION}

\section{Main conceptual CLIL frameworks}

Content and language integrated learning (CLIL) has become more and more popular in Europe since its emergence in the mid-199os. It is a 'dual focused educational approach in which an additional language is used for the learning and teaching of both content and language' (Coyle, Hood, \& Marsh, 2010). One of the best-known CLIL conceptual frameworks is the 4 Cs framework (culture, communication, content and cognition) (Coyle et al., 2010) embedded in a relevant context, which can provide a background for the development of all CLIL activities in a given learning environment. According to Graddol (2006), a CLIL 'learner is not necessarily expected to have the English proficiency required to cope with the subject before beginning study', and this can contribute to positive engagement and motivation for students. In fact, motivation plays a key role in the attainment of learning objectives and CLIL methodology can install a 'hunger to learn' and to communicate in the student, even in the first language" (Marsh, Marsland, \& Stenberg, 2001).

Within the programme of activities developed by the ECML (European Centre for Modern Languages) for 2004-2007, an international team of experts (Anne Maljers, David Marsh, Stefka Kitanova, Dieter Wolff, and Bronislawa Zielonka) produced the 'CLIL Matrix' (http://archive.ecml.at/ mtp2/CLILmatrix/index.htm), a four-dimensional core framework built around the core elements content, language, integration and learning. These four elements are realized through a set of four parameters-culture, communication, cognition and community-and the result is the CLIL Matrix, made up of 16 indicators that can be used to help ensure quality CLIL in teaching and learning. The CLIL Matrix provides teachers with a tool for self-awareness and meta-cognition concerning the skills and competences needed to plan and implement good CLIL activities.

The twinned terms soft and hard (sometimes strong and weak) are often used in reference to CLIL curriculum to distinguish language-led approaches (soft) from content-led approaches (hard) (Kelly, 2010; Ball et al., 2015). "Soft CLIL" is more concerned about language aims, while "hard 
CLIL" focuses mainly on the delivery of subject content through the additional language.

The core features of CLIL methodology (Mehisto et al., 2008) can be presented as follows:

- multiple focus

- $\quad$ safe and rich learning environment

- authenticity

- $\quad$ active learning

- scaffolding

- co-operation.

In order to put these core features of CLIL into practice and achieve full integration between content and language, it can be helpful to support language-learning in content classes and to support content-learning in language classes (Ball et al., 2015).

Another important part of the CLIL conceptual framework is known as the CLIL pyramid (Meyer, 2010; see Figure 1), which presents an idealized process for building quality CLIL teaching/learning materials: topic selection; choice of media (study skills + input - scaffolding); task design (cognition + communication; output - scaffolding); CLIL-workout.

\section{Figure 1. CLIL pyramid}

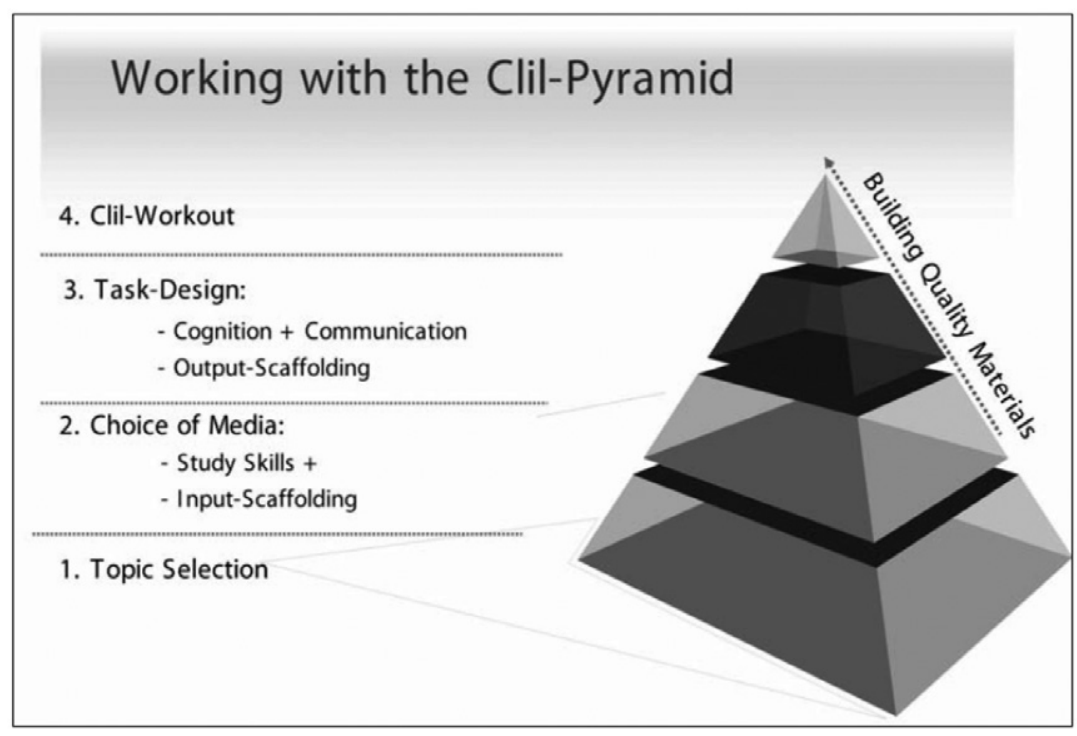

Source: Meyer (2010). 
CLIL content can be expressed in terms of three dimensions (Ball et al., 2015), which can help form the background for any CLIL activity: concept, procedure, and language. Interplay amongst these dimensions should take place regularly in CLIL classes, and teachers should be prepared to decide which dimension to prioritize in given circumstances, depending on the specific aims, the setting, and the context in which the particular teaching action is taking place.

Italian policymakers have been discussing the potential that a CLIL approach could have in terms of positively influencing student motivation towards both foreign-language learning and content learning, particularly in the light of the positive outcomes in other European countries that have experimented CLIL in recent years. Increasingly, CLIL has been recognized as a driver for higher additional-language competences and better learning outcomes in general.

\section{CLIL in Europe}

According to a European Council Resolution of 1995 students of European Union Member States 'should as a general rule have the opportunity of learning two languages of the Union other than their mother tongue(s) for a minimum of two consecutive years during compulsory schooling and if possible for a longer period' (Council of Europe, 1995, p. 4). CLIL methodology can represent a way to foster plurilingualism, as it is based on the use of a foreign language to deliver subject content: language competences are strongly fostered in a CLIL learning environment. The predecessors of CLIL may be identified with North American immersion, bilingual education programs, and European international schools (Pérez-Cañado, 2012).

Numerous authors have described and documented the rapid expansion of CLIL in the European schools (see for example Coonan 2005; Coyle et al., 2010; Dalton-Puffer \& Nikula 2006; Marsh 2002). As a result of increasing interest in the CLIL approach, a significant number of European countries decided to embed CLIL swiftly into their mainstream education, from preschool to vocational school, "borrowing" it from the academic world, to which it used to belong exclusively (Coyle, 2009). All over Europe, within a wide mosaic of national policy decisions about the organization 
of language teaching, the idea of complementing traditional foreign language teaching with the delivery of subject content through a vehicular language was perceived as an attractive and challenging approach, both at administrative and grassroots levels (Dalton-Puffer \& Nikula, 2014).

As described in the Eurydice report Key Data on Teaching Languages at School in Europe (Eurydice, 2012):

In nearly all European countries, certain schools offer a form of education provision according to which non-language subjects are taught either through two different languages, or through a single language which is 'foreign' according to the curriculum. Only Denmark, Greece, Iceland and Turkey do not make this kind of provision. (Eurydice, 2012)

Belgium, Luxembourg, and Malta are the only European countries in which CLIL provision exists in all schools throughout the whole education system. This is a potential objective for Italy in the foreseeable future. In the majority of European countries, CLIL has been first trialled through projects or pilot programs before later becoming mainstream, as in Cyprus; in some cases, CLIL is still being implemented through specific projects. Such practices are widespread in Austria (Dalton-Puffer, 2011) at secondary level and even at primary level, and in Italy a significant number of projects have been carried out by schools or school networks before CLIL became mainstream in the country.

CLIL has been defined by both the Council of Europe and the European Commission as an innovative approach that is ideal for fostering plurilingualism and improving the quality of school curricula. Therefore, the European Commission, has adopted the "CLIL label" in a number of Resolutions and Reports as part of its larger educational language policy plans (Marsh, 2013), taking advantage of a favourable political climate and seeking funds for transnational initiatives and collaboration platforms. The European Commission Staff Working Document Language Competences for Employability, Mobility and Growth (European Commission, 2012) depicts CLIL as a way to improve the quality of language education in order to prepare $21^{\text {st }}$-century professionals, as expressed in this excerpt: 
An early start for learning languages, increased offer and provision in both general education and VET, teaching of at least two foreign languages to all pupils as a part of compulsory education, increased exposure at school and through the media, reinforced motivation of pupils and special attention towards monitoring results can make the difference. (European Commission, 2012, p. 16)

Overall, the European Commission, through its Web page and its official documents, promotes the importance of plurilingual competences, bilingual education and, in particular, CLIL, as described in this quotation from European Commission (2016) Web site:

The European Commission is very keen to promote language learning and linguistic diversity across Europe so as to improve basic language skills. It is working with national governments to meet an ambitious goal: enabling citizens to communicate in 2 languages other than their mother tongue. (European Commission, 2016)

Another recent Report prepared for the European Commission (Scott \& Beadle, 2014) stresses the potential of CLIL with particular emphasis on the link between CLIL and technologies: in the twenty-first century it is essential to keep up with the latest educational and technological trends in language learning and CLIL curricula. In Italy, the link between CLIL and ICT has become particularly relevant: a National Digital School Plan (PNSD) was issued in 2015 (MIUR, 2015a) in order to change and innovate the teaching practices and the school system in general.

Nevertheless, after a period of heightening enthusiasm over the past half-decade, a more critical approach has now emerged, entailing a more sceptical analysis of some dimensions of CLIL (characterization, implementation, and research). From the lessons learnt in the past, many studies are now revisiting some aspects of the approach that were previously taken for granted, and these can be considered the greatest challenges for future CLIL theory and praxis (Pérez Cañado, 2016). 


\section{The opportunity of the Erasmus Plus programme}

CLIL and language learning in general are being promoted in Italy through the Erasmus Plus programme (http://ec.europa.eu/programmes/ erasmus-plus/), coordinated and financed by the European Commission, for Education, Training, Youth and Sport for 2014-20. The Erasmus Plus programme aims to boost skills and employability, as well as to modernize education, training, and youth work. It provides opportunities for over 4 million Europeans to study, train, gain work and volunteer experience abroad. It is aimed at supporting transnational partnerships among institutions and organizations to foster cooperation and build a bridge between the world of education and the world of work. Thanks to Erasmus Plus, schools can apply for support to enhance teachers', students' and administrators' mobility outside their countries of employment, in order to spend a certain number of weeks directly involved in classes for job-shadowing or just to experience in person the teaching/learning of subject content through a foreign language. Schools can be financed for their own Erasmus Plus projects in a network with other schools, institutions, or universities from other EU countries.

Many interesting Erasmus Plus projects focused on CLIL were financed in the first two years of the Programme, and more opportunities are expected to come. One example of a project considered a success story was Tools for CLIL language Teachers that came out of the LLP Programme (Life-Long Learning Programme, the Programme for 2007-2014, before Erasmus Plus), having produced valuable outcomes in the form of a free repository of online tools and resources for use in class. ${ }^{1}$

\section{EVOLUTION OF CLIL IN ITALY}

\section{CLIL in the Italian school curricula ${ }^{2}$}

In Italy, the first experiments with CLIL methodology, dating back to the early 1990s, were carried out mainly in international or European schools.

1 http://ec.europa.eu/programmes/erasmus-plus/projects/eplus-project-detailspage/?nodeRef=workspace://SpacesStore/82d89d4e-e381-42ff-b72f-fc9a11f3c674

2 The official website of the Italian Ministry of Education that collects information and decrees concerning CLIL in Italy is available at http://hubmiur.pubblica.istruzione.it/ web/istruzione/dg-ordinamenti/clil 
Particularly, CLIL found a welcoming context in the country's northern regions, where multilingualism has been a traditional part of the cultural background: for example, in Valle d'Aosta, French and Italian are both official languages (Lucietto, 2010); in Friuli-Venezia Giulia, Slovene is another language spoken; in the province of Bolzano, German is widespread. (See also the "Some successful projects" section of this article for brief discussion of some projects carried out in Lombardy.)

Following the recent Reform of Italy's second cycle of education in 2003, implemented through Ministerial Decrees 87, 88, and 89 in 2010, the curricula in upper secondary schools have been revised, identifying three different kinds of schools: licei, istituti tecnici, and istituti professionali. National Guidelines (MIUR, 2010a; 2010b; 2010c; 2010d) issued by the Ministry of Education describe specific learning objectives for each type of upper secondary school, also including the students' educational, cultural and professional profiles (PECUP), representing what students should know and be able to do at the end of their studies.

One of the main aims of this Reform was to reduce the very high number of specializations in upper secondary schools, which could be confusing for the students. Another important objective was to introduce the concept of competences, in accordance with the Eight Key Competences Framework (European Parliament, 2006). In line with this Framework, standards for language competence were also set, as they had not been clearly defined before. Table 1 briefly describes the different types of upper secondary schools after the Reform (Eurydice, 2013).

As a part of Italian school policy, the Reform Law also introduced CLIL as mandatory in licei and istituti tecnici, according to the following instructions:

- the teaching of a subject in a foreign language is to be offered in the final (fifth) year at licei; any curricular subject can be chosen;

- the teaching of a subject in a foreign language is to be offered in the final (fifth) year at technical schools; the subject must belong to "specialization" area;

- the teaching of two subjects in two foreign languages is to be offered in the final three years at licei linguistici. 
Table 1. Italian upper secondary schools after the Reform

\begin{tabular}{|l|l|l|}
\hline \multicolumn{1}{|c|}{ Licei } & Istituti tecnici (Technical) & \multicolumn{1}{|c|}{ Istituti professionali (Vocational) } \\
\hline $\begin{array}{l}\text { Liceo Artistico: } \\
\text { fine arts, design, } \\
\text { photography, sculpture etc. }\end{array}$ & $\begin{array}{l}\text { Indirizzo tecnologico: } \\
\text { technical skills such as } \\
\text { mechanics, logistics, } \\
\text { electronics etc. }\end{array}$ & $\begin{array}{l}\text { Indirizzo dei servizi: } \\
\text { agriculture, health and social } \\
\text { services, hospitality and gastronomy, } \\
\text { commerce. }\end{array}$ \\
\hline $\begin{array}{l}\text { Liceo Classico: } \\
\text { classical languages, } \\
\text { philosophy and literatures. }\end{array}$ & $\begin{array}{l}\text { Indirizzo economico: } \\
\text { administration, } \\
\text { accounting, marketing or } \\
\text { tourism. }\end{array}$ & $\begin{array}{l}\text { Indirizzo dell'industria e } \\
\text { dell'artigianato: } \\
\text { industrial and craft production, } \\
\text { technical assistance and } \\
\text { maintenance. }\end{array}$ \\
\hline $\begin{array}{l}\text { Liceo Scientifico: } \\
\text { biology, chemistry, physics } \\
\text { and maths. }\end{array}$ & \\
\cline { 1 - 2 } $\begin{array}{l}\text { Liceo Linguistico: foreign } \\
\text { languages, cultures and } \\
\text { literatures. }\end{array}$ & & \\
\cline { 1 - 2 } $\begin{array}{l}\text { Liceo musicale e coreutico: } \\
\text { music and dance. }\end{array}$ & \\
\cline { 1 - 2 } $\begin{array}{l}\text { Liceo delle scienze umane: } \\
\text { humanities and } \\
\text { psychology. }\end{array}$ & & \\
\hline
\end{tabular}

School year 2012-13 was the first year of implementation for licei linguistici, while in school year 2014-15, these innovations reached all licei and technical schools.

The introduction of CLIL was a real revolution for Italian upper secondary schools, confirming the understanding of CLIL as a driving force for innovation and revolution that impacts all stakeholders in a school community (Mehisto et al., 2008). In this way, Italy is in falling into line with the majority of other European countries, which have been experimenting CLIL for long time. The policy makers' decision to adopt the teaching of non-linguistic subjects through a foreign language in the last year of upper secondary schools shows that the Italian Ministry of Education understands how CLIL can contribute to improving the quality of school curricula and better meet $21^{\text {st }}$-century challenges, following the above mentioned European Commission recommendations. This represents a clear break from teacher-centred lecturing towards learner-centred ways of learning, which is one of the strongest innovations incorporated in CLIL approaches, in response to one of the greatest challenges currently faced by Italian schools. 
In the progressive process from pre-CLIL to full CLIL, the precursory phase in Italian schools was often mediated through the use of the L1: a sort of "maieutic CLIL" (Agolli, 2015), based on translanguaging (CLSL model), not adopting translation as a teaching technique, but code-switching aimed at conceptualizing learners' proficiency in both content and language areas. The importance of the interplay between L1 and L2 is also emphasized in a study on a cooperative project between an English for Specific Purposes practitioner and a teacher of Business Organization at university level (Cianflone \& Coppolino, 2011).

\section{CLIL teacher profile}

Through a specific Decree (D.D. n.6 dated 16 April 2012) (MIUR, 2012), the Italian Ministry of Education established the characteristics of the Italian CLIL teacher profile (summarized in Table 2), specifying the different skills and competences a CLIL teacher must develop in order to be fully qualified. Three dimensions of competences must be interwoven in a CLIL teacher: language competences, subject competences, teaching competences. The profile is quite complex and demanding, if we consider the different specific skills to be developed.

\section{Table 2. Italian CLIL teacher profile (English version)*}

\section{Language dimension:}

The teacher

- has a C1 level of competence in the foreign language (CEFR)

- is able to manage, adapt and use subject materials in the foreign language

- has a mastery of the specific subject language (specific lexicon, discourse types, text genres and forms) and of the subject concepts in the foreign language.

\section{Subject dimension:}

\section{The teacher}

- is able to use the subject knowledge according to the national curricula of the relevant school level

- is able to teach the subject content integrating language and content.

\section{Methodological dimension:}

The teacher

- is able to plan CLIL paths in cooperation with language teachers and teachers of other subjects

- is able to find, choose, adapt, create materials and resources to enhance the CLIL lesson also using ICT

- is able to plan a CLIL path autonomously, using methodologies and strategies aimed at fostering the learning of content through the foreign language

- is able to identify, create and use assessment tools which are consistent with CLIL methodology.

\footnotetext{
* Translated by the author. The Italian version is available in Annex 1.
} 
In defining the Italian CLIL teacher profile, a key role was played by inspector Gisella Langé (Marsh \& Langé, 2000), well known in the CLIL field throughout Europe and beyond. Langé coordinated different Working Groups on CLIL at the Italian Ministry of Education (in which the author of this paper was an active member), designing the different dimensions of professional competence in a manner that was completely new to the Italian school system. This work was supported by guidance from the Framework for CLIL Teacher Education (Marsh, Mehisto, Wolff, \& Frigols, 2010), whose authors were often invited to Italy as speakers at conferences, seminars and ministerial meetings so that Italian educators could draw more directly on their knowledge and experience. Opinions, experience, and expertise were likewise solicited from numerous other experts and university professors to help policy makers develop documentation relevant to the CLIL teacher profile and CLIL teacher training.

\section{Training pathways}

Through the above-mentioned Decree (MIUR, 2012), the Italian Ministry of Education established the CLIL teacher profile described in the previous section (CLIL teacher profile), and thence relevant criteria for CLIL methodology courses in order to offer teachers the required training in the competences needed to teach a subject through a foreign language. These CLIL training courses are addressed to in-service non-linguistic subject teachers and are structured as follows:

- language courses starting at least from level B1 of the CEFR (Common European Framework of reference) and targeting level $\mathrm{C}_{1}$;

- CLIL methodological courses designed as university post-graduate courses (20 University Credits - 500 hrs).

In accordance with the Ministerial Decree of 10 September 2010, $\mathrm{n}$. 249, art. 14 (MIUR, 2010a), which describes CLIL training courses for initial teacher training (ITT), a longer methodological course was designed for ITT: the pre-requisite is a $\mathrm{C}_{1}$ language level, and the course offers 60 credits of activities, for an equivalent of 1500 hours.

The target language-level for CLIL teachers takes into account the standards set by the Italian Ministry of Education through the aforementioned Indicazioni Nazionali per i Licei (National Guidelines), through which 
general linguistic and communicative objectives for students are offered and a B2 level in English is the expected outcome. The Italian Ministry of Education opted to train DNL (discipline non linguistiche, "nonlinguistic disciplines") teachers as CLIL teachers; however, it is a considerable challenge to prepare such content teachers the required levels of proficiency in a foreign language, as this was not previously mandatory within the Italian educational system. Methodological courses on CLIL began to be delivered by Italian universities in 2013 and a variety of different courses all over Italy have been launched since. Table 3 presents an Annex to the aforementioned Ministerial Decree n.6/2012 and includes specific dimensions for CLIL training pathways and learning content:

- basic training activities: theoretical and methodological transversal aspects, preparatory to the following part of the training;

- $\quad$ specializing training activities: subject contents delivered in a foreign language according to CLIL approaches, using active learning methodologies and laboratories in order to achieve real integration between language and subject; a portion of the training activities on subject-content delivery must be carried out through co-teaching with a foreign language trainer;

- $\quad$ Practicum through Action-Research in class and a final exam.

\section{Table 3. CLIL methodological courses}

\begin{tabular}{|c|c|c|c|}
\hline Attività formative & Ambito disciplinare & $\begin{array}{l}\text { Settore scientifico- } \\
\text { disciplinare (SSD) }\end{array}$ & $\begin{array}{l}\text { Crediti Formativi } \\
\text { Universitari (CFU) }\end{array}$ \\
\hline di base. & $\begin{array}{c}\text { Aspetti teorici e } \\
\text { metodologici trasversali, } \\
\text { come elementi di } \\
\text { partenza per i laboratori } \\
\text { previsti nelle attività } \\
\text { formative caratterizzanti. }\end{array}$ & $\begin{array}{l}\text { SSD L-LIN/O2 e SSD } \\
\text { L-LIN* di tutte le lingue } \\
\text { purché vengano } \\
\text { attivati insegnamenti } \\
\text { di contenuto } \\
\text { glottodidattico. }\end{array}$ & 9 \\
\hline $\begin{array}{l}\text { caratterizzanti (i CFU da acquisire } \\
\text { in queste attività formative } \\
\text { caratterizzanti avranno forma } \\
\text { primariamente laboratoriale e } \\
\text { dovranno portare ad una effettiva } \\
\text { integrazione tra gli insegnamenti } \\
\text { impartiti). }\end{array}$ & $\begin{array}{l}\text { Didattiche disciplinari } \\
\text { in prospettiva veicolare } \\
\text { (CLIL). }\end{array}$ & $\begin{array}{l}\text { SSD delle discipline da } \\
\text { veicolare } \\
\text { SSD L-LIN/O2 e SSD L } \\
\text { - LIN }\left(^{*}\right) \text { della lingua } \\
\text { scelta. }\end{array}$ & $\begin{array}{l}\text { 9 CFU delle } \\
\text { discipline } \\
\text { linguistiche, } \\
\text { di cui } 3 \text { CFU in } \\
\text { copresenza con } \\
\text { le discipline da } \\
\text { veicolare }\end{array}$ \\
\hline $\begin{array}{l}\text { Altre attività (tirocinio CLIL con } \\
\text { modalità di ricerca- azione anche } \\
\text { a distanza e colloquio finale). }\end{array}$ & & & $2 \mathrm{CFU}$ \\
\hline \multicolumn{3}{|c|}{ Totale } & $20 \mathrm{CFU}$ \\
\hline
\end{tabular}


While methodological CLIL courses can be given only by universities, language courses aiming at bringing students to $\mathrm{C} 1$ level can be also organized by other training institutes and centers, thereby offering teachers a wider range of opportunities to develop their language competences. Outcomes from experiences with the methodological CLIL courses have been presented in various seminars and conferences organized by universities in many Italian regions and through these, participants have opportunities to express their opinions and give feedback on the courses. A large number of universities carried out monitoring projects to investigate the impact of the courses on the participants and the outcomes have been collected in specific research reports.

\section{Transitory norms}

In January 2013 and in July 2014, the Italian Ministry of Education issued documents identified as Norme transitorie ("Transitory norms") (MIUR, 2014) for licei and technical schools, giving hints and suggestions on how to implement CLIL in the classroom.

These included the creation a 'Team CLIL' for given teaching contexts: a group involving different professionals working in cooperation with a DNL teacher. Forms of cooperation and team-teaching had already been trialled in Italy. For example, in the autonomous province of Trento, which is now engaged in a very challenging policy of trilingualism, the TATEO (TAlking To Each Other) model involved teaching teams made up of a FL (Foreign Language) teacher, a subject teacher and an external consultant working together with the aim of cooperating on planning and implementing CLIL activities in the perspective of an effective professional dialogue (Lucietto, 2009).

The Norme transitorie also suggested that approximately 50\% of a subject's contact-hours should be taught through the foreign language. Other suggestions were for cooperation between different schools through networks and the use of multimedia and digital devices in order to enhance the potential of CLIL lessons, as well as webinars with experts or creating links with other schools abroad. Cooperation among all the school stake- 
holders, as suggested by the Italian Ministry of Education is intended to facilitate the introduction of CLIL in schools.

\section{The "Good School Reform"}

In July 2015, the Italian Parliament approved Law n.107, named La Buona Scuola ('The Good School') (MIUR, 2015), covering different areas of the school sector, including provisions aimed at strengthening language activities and the introduction of CLIL from the primary level and upward. According to this law, for both the school years 2015-16 and 2016-17, the Directorate General for school curricula of the Italian Ministry of Education invited proposals for financing CLIL projects at any school level (primary, lower and upper secondary), based on innovative teaching strategies and learning environments. Within the framework of La Buona Scuola, the recently approved National Teacher Training Plan (MIUR, October 2016) is aimed at reshaping teachers' on-going professional development, making this structural and compulsory: language competences and CLIL are top priorities for 2016-2019, and a large number of training programmes involving both foreign language teachers and subject teachers at all school levels are to be activated during this period.

\section{CURRENT STATUS OF CLIL IN ITALY}

\section{CLIL at licei linguistici}

The licei linguistici were the first Italian secondary schools to be involved in CLIL methodology, starting from the third classes in 2012. A monitoring report ${ }^{3}$ issued in 2014 (MIUR, 2014a) collected the results of the first year of experimentation (2012-13) and was presented at a conference at the Italian Ministry of Education in Rome. The report presents an interesting picture of Italian schools, as they seek the best practices for implementing CLIL within the curriculum; a more in-depth study of student learning outcomes has not yet been carried out, though it is hoped that this will be

3 The author was directly involved in the research project while working for the Ministry of Education. 
done within the next few years. Nevertheless, the abovementioned monitoring report gives some hints and reflections on how the implementation of CLIL has so far impacted schools: in particular, teachers attest they have discovered new ways of teaching through CLIL and have in many cases completely changed their teaching strategies.

The most popular foreign language for CLIL in Italy is English, followed by French; Spanish and German are both taught in a very small percentage ( $4 \%$ ), as the graph from the report (Figure 2) shows:

\section{Figure 2. Languages taught (after Monitoring Report, 2014, p. 17)}

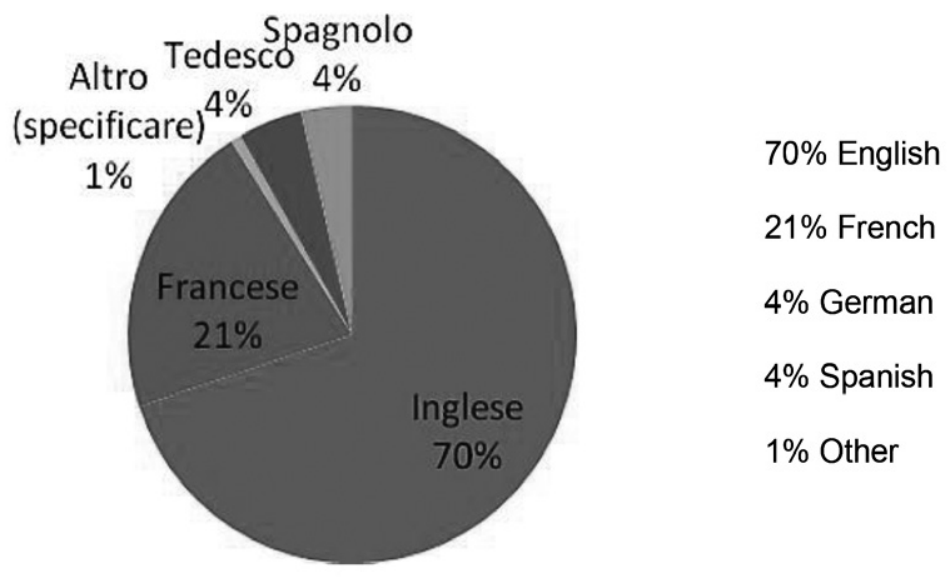

As for the subjects taught in a foreign language, history seems to be the most popular subject, followed by the natural sciences, physics, philosophy, mathematics, history of art, and sports, as shown in Figure 3.

Figure 3. Subjects for CLIL (after Monitoring Report, 2014, p. 17)

\begin{tabular}{lrr|r} 
Other subjects & 4,58 & Altri insegnamenti di cui all'allegato H del D.P.R... & \multicolumn{1}{c}{4,58} \\
Sports & 4,79 & scienze motorie e sportive & 4,79 \\
History of Art & 7,41 & storia dell'arte & 7,41 \\
Maths & 8,28 & matematica & 8,28 \\
Philosophy & 9,15 & filosofia & 9,15 \\
Physics & 13,07 & fisica & \\
Natural science & 18,74 & scienze naturali & \\
History & 32,03 & storia & 13,07 \\
& & &
\end{tabular}




\section{Some successful projects}

One pioneering CLIL project in Italy, carried out in the region of Lombardy from 2001-2006, was Progetto Lingue Lombardia ('Lombardy Languages Project'); also in Lombardy, the IBI/BEI (Bilingual Education Italy) project was developed by the Directorate for School Curricula of the Ministry of Education in cooperation with the Regional Education Authority in Lombardy and the British Council. The IBI/BEI 4 project involved 6 primary schools in Lombardy with teachers competent in the English language (minimum B2 level), offering at least 25\% of the curriculum in English. Target subjects were generally Art, Geography, and Science. The project started in 2010, in the first classes of the primary schools and was monitored by the Ministry and by the British Council: a monitoring report was issued in 2014 (MIUR, 2014b). In this project, quantitative and qualitative methods, using surveys and interviews with different stakeholders, as well as classroom observation activities, reveal positive outcomes in terms of student and parental satisfaction, motivation, and enthusiasm. The pupils themselves were all aware of the privilege they were given through this project. Participating students were found to have attained better learning outcomes and a higher level of competence in English in comparison with non-IBI/ BEI students-as well as a wider mastery of the first language. Additionally, participating teachers had better professional development both in the language and the content areas.

As for upper secondary schools, another pioneer project developed by the Directorate for School Curricula of the Italian Ministry of Education in 2011 was the E-CLIL project which involved a network of schools all over Italy (Langé \& Cinganotto, 2014). ${ }^{5}$ It was aimed at helping teachers plan and implement CLIL modules in their classes with the use of Web tools, digital devices, and ICT in general. A scientific committee coordinated by Langé (the author of this paper was then this project's contact person at the Ministry of Education) developed guidelines for the project and

\footnotetext{
4 The author was a member of IBI/BEI Steering Committee.

5 Information about the E-CLIL project is available from http://hubmiur.pubblica.istruzione.it/alfresco/d/d/workspace/SpacesStore/9oce1993-e3ba-4fc8-916b-171292f31eag/ linee_guida_progetto_eclil.pdf
} 
outputs were presented in a volume (Langè \& Cinganotto, 2014) collecting all the relevant documents, guidelines, and reports, together with the most significant CLIL modules planned and implemented in the schools, representing a valuable repository of resources for teachers, trainers, and students in Italy —and, indeed, around the world. Videos produced by participating E-CLIL schools clearly show teachers' and students' enthusiasm for and engagement with the project; they were willing to discover new frontiers and experiment with innovative ways of teaching and learning.

The abovementioned projects were aimed at guiding the Italian school system to approach CLIL; they were informed by the ongoing educational reforms but, at the same time, they also provided important, even if preliminary, feedback on these initial process and the relative impact of introducing CLIL, thus representing a valuable resource for educational policy makers in subsequent steps.

\section{Some challenges for the future}

One of the most challenging issues to emerge from the implementation of CLIL in Italy concerns team-teaching, which is one of the approaches recommended by the Ministry of Education through the aforementioned Norme transitorie: DNL teachers are supposed to cooperate with language teachers and other experts at schools. Team-teaching does not imply any investments for schools, yet it has turned out to be quite difficult to put into practice, since no additional costs can actually be considered and a school's "Team CLIL" is supposed to work mainly on other matters, such as developing materials, planning lessons, and building CLIL syllabi. Such tasks are often perceived as time-consuming and too demanding for the teachers.

Coonan $(2008,2011)$ notes that most of these kinds of problems stem from the fact that, until recently, there were no language target-level standards for teachers in general and for CLIL teachers in particular. Coonan's proposal (2012) is to let students benefit from their language teachers by doing some activities with them that are closely related to the specific topic being taught through the CLIL approach, especially if the teacher is still undergoing his/her own CLIL training; this may serve as encouragement to deeper collaboration between the language teacher and the 
subject teacher, in line with the "Team CLIL" approach suggested by the Ministry of Education.

Another challenging issue is represented by CLIL teacher training itself. The training demands are very high and for some teachers, the two training pathways (one in the target language and the other on CLIL methodology) are too time-consuming; while they are studying, teachers also have to keep up with their existing work, as well as family commitments. So far, in comparison the number of classes throughout Italy in which CLIL is theoretically mandatory, only a small percentage of teachers have already been trained or are currently being trained. Even so, the teachers who have studied hard and completed the training pathways with successful results (achieving both the $\mathrm{C}_{1}$ level certificate in the target language and the CLIL methodology course certificate) provide encouragement for universities, trainers, policymakers, and for the Ministry itself. Fortunately, La Buona Scuola Reform has allotted significant levels of funding for teacher training over the coming years, in accordance with the aforementioned National Teacher Training Plan. As for recognition of teachers' efforts and merit, it is important that the Italian Ministry of Education has recognized CLIL methodology courses within their mobility scheme, meaning that teachers with the relevant qualifications asking to be moved from one school to another have higher chances of getting the requested transfer.

Another challenge faced by Italian CLIL teachers is the lack of material for their lessons: the book market has been growing in the CLIL sector in recent years, but it is still difficult to balance the content delivery with the relevant language level, considering that much of the available online teaching materials for non-linguistic content-teaching is designed and intended mainly for native speakers. The recent National Digital School Plan (PNSD) is aimed to help Italian teachers better plan and implement CLIL activities through the use of ICTs as well as through the production of their own original digital content, in accordance with the latest innovative teaching models, such as flipped classrooms or the BYOD model (Bring Your Own Device). A further challenge is represented by approaches to assessment in CLIL; Italian content teachers are used to assessing the students on the subject they are specialized in, but in a CLIL curriculum both content and language must be assessed. 
With the aim of better understanding teachers' experiences with and future expectation about CLIL (attitudes, behaviours, reasons for concern), in 2011, Suor Orsola Benincasa University (Di Sabato \& Di Martino, 2012) implemented a survey with a sample of teachers from the province of Naples (52 upper secondary school teachers). The following weaknesses, largely summarizing what has been expressed throughout this section of the present article, emerged:

- organization and planning both at individual and at school level.

- the teachers' preparation and commitment.

- difficulty in researching and selecting adequate materials.

- $\quad$ extra work for the teachers involved.

- difficult relationship between the foreign language component and the content language component of the curriculum (that is, between the two teachers of, respective, language and of content).

- the students' level of competence not only in the foreign language but also in their first language.

- the assessment of students.

Participating teachers expressed their concerns about the weak competences of some of their colleagues, their fear that content learning may be slowed down by CLIL and their worries about Italian teachers' ability to really work cooperatively, adopting cross-curricular and transversal teaching strategies. Therefore, it is clear that the Italian education system will continue to face a number of challenges in the coming years.

\section{CONCLUSIONS}

Italy has made very important steps forward in its educational system by pursuing the implementation of CLIL, made mandatory through a Reform Law. Italian policy makers believe strongly in CLIL, though it is recognized that much remains to be done to establish CLIL as an integral and natural part of school curricula in all Italian schools. Indeed, situational context can differ radically from school to school, depending on different factors including administrators' attitudes toward CLIL, teachers' good will toward starting a challenging new adventure, a given school's technical equipment and the educational network in which the school may be involved. However, new 
inputs and funds will come from the ongoing implementation of La Buona Scuola Reform Law (Law 107/2015), on which policy makers are still working hard with regard to all the issues and dimensions involved.

Yet, in general, we can say that the results of the ongoing CLIL implementation in Italy have been quite satisfactory and rewarding. A research project being carried out by "Università Cattolica del Sacro Cuore" in Milan on behalf of the Ministry of Education involving a monitoring action on CLIL provision in licei linguistici is expected to provide updated picture of the state of the art of CLIL implementation in this type of school, offering the opportunity to compare it with the previous monitoring report referring to school year 2012-13. ${ }^{6}$

Step by step, critical issues are being faced and necessary adjustments are being made. Implications and resonances of the progressive implementation and spreading of CLIL in Italy should continue to be reflected by developments in the educational system as a whole, impacting curricular subjects, foreign languages, internationalization of the curricula and bringing renewed energy and enthusiasm to teachers, students, families and the whole educational community. The collective experience coming from Italian CLIL schools today will help construct a better future tomorrow and offers lessons and examples well worth considering in other contexts around the world.

\section{ACKNOWLEDGMENTS}

The author is thankful to inspector Gisella Langé from the Italian Ministry of Education for her suggestions and hints included in this contribution. The author has been cooperating a lot with the inspector while working for the Italian Ministry of Education until 2014.

6 At the time of writing, information on this project, coordinated by prof. Maria Teresa Zanola on behalf of "Università Cattolica del Sacro Cuore" (Milan) and by inspector Gisella Langé on behalf of the Ministry of Education, is being made available at http:// selda.unicatt.it/milano-clil-azioni-e-repository.

The author has been a member of the Steering Committee of the project. 


\section{REFERENCES}

Agolli, R. (2015). Content and Language symbiosis in a maieutic, translanguaging pattern (CLSL): An exploratory practice in Italy. Latin American Journal of Content and Language Integrated Learning, 8(1), 43-54.

Ball, P., Kelly, K., Clegg, J. (2015). Putting CLIL into practice. Oxford, UK: Oxford University Press.

Cianflone, E. \& Coppolino, R. (2011). An interdisciplinary module to teach English and Business Organization in a university-level vocational course. Latin American Journal of Content \& Language Integrated Learning, 4(1), 40-48.

Coonan, C.M. (2005). The natural learning of a foreign language: CLIL as a possible partial solution for the primary school. Scuola e Lingue Moderne, 4/5, 4-11.

Coonan, C. M. (2008) Insider views of the CLIL class through teacher selfobservation-introspection. International Journal of Bilingual Education and Bilingualism, 10(5), 625-646.

Coonan, C. M., (2011). CLIL in (language) teacher training. Studi di Glottodidattica, 2, 1-14.

Coonan, C. M., (2012). The foreign language curriculum and CLIL. Synergies Italie, 8, 117-128.

Council of Europe. (1995). Council resolution of 31 March 1995 on improving and diversifying language learning and teaching within the education systems of the European Union. Official Journal of the European Union, C 207, 1-5.

Coyle, D. (2009). Language pedagogies revisited: Alternative approaches for integrating language learning, language using and intercultural understanding. In J. Miller, A. Kostogriz, \& M. Gearon (Eds.), Culturally and linguistically diverse classrooms: New dilemmas for teachers (pp. 172-195). Bristol, UK: Multilingual Matters.

Coyle, D., Hood, P. \& Marsh, D. (2010). CLIL: Content and language integrated learning. Cambridge, UK: Cambridge University Press.

Dalton-Puffer, C. \& Nikula, T. (2015). Guest editorial. The Language Learning Journal,43(3), 235-238. http://dx.doi.org/10.1080/09571736.2015.1053277 
Dalton-Puffer, C. \& Nikula, T. (2006). Introduction. Vienna English Working Papers, 15(3), 4-7.

Dalton-Puffer, C., Faistauer, R. \& Vetter, E. (2011). Research on language teaching and learning in Austria (2004-2009). Language Teaching, 44(2), 181-211. http://dx.doi.org/10.1017/So261444810000418

Di Martino, E. \& Di Sabato, B. (2012). CLIL implementation in Italian schools: Can the long ago employed teacher be trained effectively? The Italian protagonists' voice. Latin American Journal of Content and Language Integrated Learning, 5(2), 73-105. http://dx.doi. org/10.5294/laclil.2012.5.2.9

European Commission. (2012). Language competences for employability, mobility and growth (Commision Staff Working Document No. SWD/2012/0372). Strasbourg, France: European Commission. Retrieved from http://eur-lex.europa.eu/legal-content/EN/ TXT/?uri=CELEX:52012SCO372

European Commission. (2016). Multilingualism. Retrieved from http:// ec.europa.eu/education/policy/multilingualism_en

European Parliament. (2006). Recommendation 2006/962/EC of the European Parliament and of the Council of 18 December 2006 on key competences for lifelong learning. Retrieved from: http://eurlex.europa.eu/legal-content/EN/TXT/?uri=URISERV:c1109o

Eurydice. (2013). The Italian educational system. Retrieved from: http:// www.indire.it/lucabas/lkmw_file/eurydice///sintesi_sistema_ educativo_italiano_EN.pdf.

Eurydice. (2012). Key data on teaching languages at school in Europe. Retrieved from http://eacea.ec.europa.eu/education/eurydice/ documents/key_data_series/143en.pdf.

Graddol, D. (2006). English next: Why global English may mean the end of "English as a foreign language." London, UK: The British Council.

Kelly, K. (2010). Interview with Keith Kelly (Chris Baldwin, Ed.). Retrieved from: https://www.teachingenglish.org.uk/article/interviewkeith-kelly

Langé, G., \& Cinganotto, L. (Eds.). (2014). E-CLIL per una didattica innovativa. Torino, Italy: Loescher. 
Lucietto, S. (2010). Studio documentale e raccolta dati utili alla valutazione del Programma di Sperimentazione "Scuole Plurilingui", Provincia Autonoma di Trento (Unpublished doctoral dissertation). Free University of Bolzano, Bolzano, Italy.

Lucietto, S. (2009). TATEO: A school- and action research-based continuous professional development model for experienced/senior secondary teachers new to CLIL. In D. Marsh, P. Mehisto, R. Aliaga, T. Asikainen, M. Frigols, S. Hughes, \& G. Lange (Eds.), CLIL practice: Perspectives from the field (pp. 117-124). Jyväskylä, Finland: University of Jyväskylä.

Marsh, D. (Ed.). (2002). CLIL/EMILE. The European dimension. Actions, trends, and foresight potential. Jyväskylä, Finland: University of Jyväskylä.

Marsh, D. (2013). The CLIL trajectory: Educational innovation for the 21st century iGeneration. Córdoba, Spain: Universidad de Córdoba Servicio de Publicaciones.

Marsh, D. \& Langé, G. (Eds.). (2000). Using languages to learn and learning to use languages. An introduction to content and language integrated learning for parents and young people. Jyväskylä, Finland: University of Jyväskylä.

Marsh, D., Marsland, B. \& Stenberg, K. (2001). Integrating competencies for working life. Jyväskylä, Finland: University of Jyväskylä.

Marsh, D., Mehisto, P., Wolff, D. \& Frigols, M. J. (2010). Framework for CLIL teacher education: A framework for the professional development of CLIL teachers. Graz, Switzerland: European Centre for Modern Languages.

Mehisto, P., Marsh, D. \& Frigols-Martín, M. J. (2008). Uncovering CLIL: Content and language integrated learning in bilingual and multilingual education. Oxford, UK: Macmillan Education.

Meyer, O. (2010). Towards quality CLIL: Successful planning and teaching strategies. Puls, 10, 11-29.

MIUR. (2010a). Decreto ministeriale 249/2010. Retrieved from http://www. miur.it/Documenti/universita/Offerta_formativa/Formazione_ iniziale_insegnanti_corsi_uni/DM_10_092010_n.249.pdf 
MIUR. (2010b). Indicazioni nazionali per i licei. Retrieved from http:// nuovilicei.indire.it/content/index.php?action=lettura\&id_ $\mathrm{m}=7782$ \&id_cnt $=10497$

MIUR. (2010c). Linee guida per gli istituti tecnici. Retrieved from http:// www.indire.it/lucabas/lkmw_file/nuovi_tecnici/INDIC/_LINEE_ GUIDA_TECNICI_pdf

MIUR. (2010d). Linee guida per gli istituti professionali. Retrieved from http:// www.indire.it/lucabas/lkmw_file/nuovi_professionali/linee_ guida/_LINEE\%2OGUIDA\%2OISTITUTI\%20\%20PROFESSIONALI_.pdf MIUR. (2012). Decreto direttoriale n. 6 del 16 aprile 2012. Retrieved from: http://hubmiur.pubblica.istruzione.it/alfresco/d/d/workspace/ SpacesStore/eo79c910-cc4e-4eab-b3db-fc9f8da55099/dd6_ profilo_docenteclil.pdf

MIUR. (2014). Norme transitorie per l'a.s. 2014-15. Retrieved from http:// www.istruzione.it/allegati/2014/Norme_Transitorie_CLIL_Licei_ Istituti_Tecnici_Lug2014.pdf

MIUR. (2014a). Rapporto di monitoraggio CLIL nei licei linguistici a.s. 201213. Retrieved from http://www.istruzione.it/allegati/2014/CLIL_ Rapporto_050314.pdf

MIUR. (2014b). Sintesi rapporto di monitoraggio progetto IBI/BEI. Retrieved from https://www.britishcouncil.it/sites/default/files/final_ sintesi.pdf

MIUR. (2015). Legge 107/2015 ["La Buona Scuola"]. Retrieved from http:// www.gazzettaufficiale.it/eli/id/2015/07/15/15Goo122/sg

MIUR. (2015a). Piano nazionale scuola digitale. Retrieved from http://www. istruzione.it/scuola_digitale/index.shtml

MIUR. (2016). Piano nazionale per la formazione dei docenti (2016-19). Retrieved from http://www.istruzione.it/allegati/2016/Piano_ Formazione_zott.pdf

Pérez-Cañado, M. L. (2012). CLIL research in Europe: Past, present, and future. International Journal of Bilingual Education and Bilingualism. http://dx.doi.org/10.1080/13670050.2011.630064 
Pérez Cañado, M.L. (2016). From the CLIL craze to the CLIL conundrum: Addressing the current CLIL controversy. Bellaterra Journal of Teaching \& Learning Language \& Literature, 9(1), 9-31.

Scott, D. \& Beadle, S. (2014). Improving the effectiveness of language learning:

CLIL and Computer Assisted Language Learning.Brussels, Belgium: European Commission. Retrieved from http://ec.europa.eu/ languages/library/studies/clil-call_en.pdf

Wolff, D. (2005). Content and Language Integrated Learning, HAL, 5, 1-22.

\section{APPENDIX}

This appendix presents the original Italian-language version of the CLIL teacher profile in Table 4.

\section{Table 4. The CLIL teacher profile (Italian version)}

\section{Ambito linguistico:}

- ha una competenza di Livello C1 nella lingua straniera

- ha competenze linguistiche adeguate alla gestione di materiali disciplinari in lingua straniera

- ha una padronanza della microlingua disciplinare (lessico specifico, tipologie di discorso, generi e forme testuali, ...) e sa trattare nozioni e concetti disciplinari in lingua straniera.

\section{Ambito disciplinare:}

- è in grado di utilizzare i saperi disciplinari in coerenza con la dimensione formativa proposta dai curricula delle materie relative al proprio ordine di scuola

- è in grado di trasporre in chiave didattica i saperi disciplinari integrando lingua e contenuti.

\section{Ambito metodologico-didattico:}

- è in grado di progettare percorsi CLIL in sinergia con i docenti di lingua straniera e/o di altre discipline

- è in grado di reperire, scegliere, adattare, creare materiali e risorse didattiche per ottimizzare la lezione CLIL, utilizzando anche le risorse tecnologiche e informatiche

- è in grado di realizzare autonomamente un percorso CLIL, impiegando metodologie e strategie finalizzate a favorire l'apprendimento attraverso la lingua straniera

- è in grado di elaborare e utilizzare sistemi e strumenti di valutazione condivisi e integrati, coerenti con la metodologia CLIL. 